\title{
Endotoxin Production by Pseudomonas aeruginosa ATCC 9027 with Potential Medical Applications
}

\author{
Moustafa Y. El-Naggar' ${ }^{1}$, Amira M. Hamdan², Ehab A. Beltagy³, Hassan A.H. \\ Ibrahim $^{3}$, and Mahetab M. M. Moustafa ${ }^{1 *}$ \\ ${ }^{1}$ Botany and Microbiology Department, Faculty of Science, Alexandria University, Alexandria, Egypt. ${ }^{2}$ Oceanography \\ Department, Faculty of Science, Alexandria University, Alexandria, Egypt. ${ }^{3}$ Microbiology Lab, National Institute of \\ Oceanography and Fisheries (NIOF), Alexandria, Egypt.
}

\begin{abstract}
Four Gram-negative bacteria (E.coli ATCC 19404, P. aeruginosa ATCC9027, A. hydrophila ATCC 7966 and V. damsel ATCC 33539) were screened for production of endotoxin. P. aeruginosa recoded the highest endotoxin concentration $\left(338.59 \times 10^{3} \mathrm{IU} / \mathrm{ml}\right)$. The optimization of endotoxin production resulted in the increase of endotoxin titer $\left(25 \%\right.$ at pH 7.0 and $26 \%$ at both $30^{\circ} \mathrm{C}$ and $\left.90 \mathrm{rpm}\right)$. The detection of lipid core complex (50 kDa) and O-specific polysccahrides $(20,25,38 \mathrm{kDa})$ was performed by the application of SDS-PAGE. GC/MS analysis indicated the presence of 4 compounds namely $2 \mathrm{H}$ Pyaran, 2,5 diethenyltetrahydro, Tetradecanoic acid, Bis(2 ethylhexyl) phthalate and Dodecanoic acid. The endotoxin was thermally stable $\left(78 \%\right.$ ) at $120^{\circ} \mathrm{C}$ for $60 \mathrm{~min}$. Reduction of endotoxin activity (45 and $69 \%$ ) occurred when treated with $1 \mathrm{~N}-\mathrm{NaOH}$ or $\mathrm{HCl}$ for $60 \mathrm{~min}$, respectively. The endotoxin showed a bio-toxicity against Artemia salina, $\left(\mathrm{LC}_{50}\right.$ of $\left.102.99 \mu \mathrm{g} / \mathrm{ml}\right)$. The endotoxin exhibited antitumor activity against colon cancer cells (Caco-2) and breast cancer cells (Mcf-7) with growth reduction amounted to $87 \%$ and $92 \%$, respectively. On the other hand, a weak antiviral activity (5.2\%) was recorded in Vero cells infected with HAV. In conclusion, the endotoxin with antioxidant property could be an alternative for the treatment of colon and breast cancer.
\end{abstract}

Keywords: Pseudomonas aeruginosa ATCC 9027, endotoxin, antitumor and antiviral activities, bio-toxicity.

*Correspondence: mahe.2003.mm@gmail.com; +201010897303

(Received: 07 February 2019; accepted: 04 March 2019)

Citation: Moustafa Y. El-Naggar, Amira M. Hamdan, Ehab A. Beltagy, Hassan A.H. Ibrahim, and Mahetab M. M. Moustafa, Endotoxin Production by Pseudomonas aeruginosa ATCC 9027 with Potential Medical Applications, J Pure Appl Microbiol., 2019; 13(1):97106 doi: 10.22207/JPAM.13.1.10

(c) The Author(s) 2019. Open Access. This article is distributed under the terms of the Creative Commons Attribution 4.0 International License which permits unrestricted use, sharing, distribution, and reproduction in any medium, provided you give appropriate credit to the original author(s) and the source, provide a link to the Creative Commons license, and indicate if changes were made. 


\section{INTRODUCTION}

Endotoxins, or bacterial lipopolysaccharides (LPS), are the main constituents ( $75 \%)$ of the outer membrane of the cell wall of all Gram-negative bacteria such as; Escherichia coli, Bordetella pertussis, Haemophilus influenzae, Salmonella, Shigella, Pseudomonas, Neisseria and Vibrio cholerae ${ }^{1,2}$. Endotoxins are heat-stable, nonproteinaceous, immunogenic compounds and can be divided into three covalently linked distinct domains: the hydrophobic "lipid A" portion, the "core" oligosaccharide and the hydrophilic "O-specific" polysaccharide region ${ }^{3}$. Lipid A is a highly conserved region and responsible for its biological toxic effect as well as beneficial activities, while the "core" is the connection part between lipid $\mathrm{A}$ and the O-specific chain ${ }^{4}$.

LPS are the causative agents for various inflammatory symptoms and pathophysiological disorders caused by Gram-negative bacterial infections $s^{2,5-7}$. However, the beneficial activities of endotoxins are protection against atopic sensitization and asthma in children and adults, induction of tumor necrosis and adjuvant activity ${ }^{8}$.

$P$. aeruginosa is considered as one of the most important causative agents responsible for life-threatening systemic infections in the intensive care units and to the immuno compromised patients ${ }^{9-11}$. However, only few reports have dealt with the antitumor and interferon-inducing activities of the LPS isolated from $P$. aeruginos $a^{12,13}$.

Thus, the current study was meant to investigate the ability of $P$. aeruginosa ATCC 9027 for endotoxin production potential under optimum cultural and environmental conditions, in addition to the characterization of the produced endotoxin. The possibility for the application potential of the produced endotoxin was also experimented.

\section{MATERIALS AND METHODS}

\section{Screening for Endotoxin Production}

\section{Bacterial strains and culture conditions}

Gram-negative bacterial isolates used for the screening for endotoxin production were; Escherichia coli ATCC 19404, Pseudomonas aeruginosa ATCC9027, Aeromonas hydrophila ATCC 7966 and Vibrio damsel ATCC 33539. The isolates were kindly provided by the Identification Unit of the Regional Center for Mycology and Biotechnology, Al-Azhar University, Egypt. Bacterial isolates were inoculated in nutrient broth medium (NB) in a rotary shaker $(120 \mathrm{rpm})$ at $37^{\circ} \mathrm{C}$ for $24 \mathrm{hrs}^{10}$.

Extraction, Detection and Measurement of endotoxin(s)

Bacterial cells were harvested by centrifugation at $4^{\circ} \mathrm{C}\left(5,000^{\prime} \mathrm{g}, 10 \mathrm{~min}\right)$ and washed twice with sterile $\mathrm{NaCl}$ solution ( $0.85 \%)$. The $S$-type LPS was extracted from the collected cells by the hot phenol-water method according to lihara et al. ${ }^{14}$. After extraction, S-type LPS was treated with RNase, DNase, and proteinase $K$ as described by Rezania et al. ${ }^{3}$. Finally, LPS were collected by ultracentrifugation $\left(4^{\circ} \mathrm{C}\right)$ at 300,000 'g for $45 \mathrm{~min}$, lyophilized and stored at $4^{\circ} \mathrm{C}$ for further use.

The detection and quantification of extracted LPS were carried out by the Limulus Amebocyte Lysate (LAL) assay using PYROGENT-5000 kit (Sigma-Aldrich, USA) according to the manufacturer instructions ${ }^{15}$.

\section{Detection of Antimicrobial Activity}

The extracted endotoxins were screened for their antimicrobial activity against selected pathogenic bacterial indicators; Salmonella typhimurium ATCC 14028, Escherichia coli ATCC 19404, Bacillus cereus ATCC 33018 and Klebsiella granulomatis ATCC 43816 , by well diffusion method $^{16}$. Overnight cultures of the test pathogens were uniformly mixed with Mueller-Hinton agar medium. Wells of $5 \mathrm{~mm}$ inner diameter were filled with the endotoxin in concentrations ranging from 10 to $120 \mu \mathrm{g} / \mathrm{l}$ and incubated at $37^{\circ} \mathrm{C}$ for $24 \mathrm{hrs}$. Then, the diameters of inhibition zones $(\mathrm{mm})$ were measured.

\section{Optimization of Fermentation Conditions}

For maximum endotoxin production, fermentation conditions were optimized based including the following factors; $\mathrm{pH}$, incubation temperature, rate of shaking and length of the incubation period. The fermentation medium was adjusted to different $\mathrm{pH}$ values ranging from $5-9$, using either $1 \mathrm{~N} \mathrm{HCl}$ or $\mathrm{NaOH}$. Furthermore, the production medium was incubated at different temperatures from in the range of $25^{\circ}-45^{\circ} \mathrm{C}$ with different rate of shaking; 90,120 and 150 rpm. Similarly, the effect of incubation period on endotoxin production was studied at $3 \mathrm{hrs}$ time intervals up to $48 \mathrm{hrs}$. For each treatment, samples were collected and analyzed for endotoxin concentration by LAL assay. 


\section{SDS-Page Analysis of LPS}

Sodium dodecyl sulfate-polyacrylamide gel electrophoresis (SDS-PAGE) was used for the characterization of S-type LPS following the procedures of Doruk et al. ${ }^{17}$. LPS bands were stained and visualized by silver staining method $^{10}$. GC/MS Analysis

Extracted endotoxin was examined by Gas Chromatography/Mass Spectrophotometer (GC/ MS-Agilent Technologies 7890A, USA) coupled to an Agilent 5975C Triple-Axis Detector, following the procedure described by Binding et al. ${ }^{18}$.

\section{Factors Affecting Endotoxin Stability Thermal stability of endotoxins}

Thermal stability of endotoxins was evaluated upon exposure to the following temperatures: $120 \div \mathrm{C}, 140^{\circ} \mathrm{C}$ and $200^{\circ} \mathrm{C}$ for 20,30 and $60 \mathrm{~min}$. Residual endotoxin concentration was measured by using the LAL assay and compared to a control set kept at $30^{\circ} \mathrm{C}$ at the same period ${ }^{19}$.

\section{Chemical stability of endotoxins}

Chemical stability of endotoxins upon treatment with $0.1,0.5$ and $1.0 \mathrm{~N} \mathrm{NaOH}$ or $\mathrm{HCl}$ was evaluated after 20,30 and $60 \mathrm{~min}$ of exposure. In addition, endotoxins were incubated with $70 \%$ and $100 \%$ ethyl alcohol for 20, 30 and $60 \mathrm{~min}$ and both were compared with endotoxin sets without treatment ${ }^{20}$. Residual endotoxin concentration was measured by using the LAL assay.

\section{Bio-Toxicity Assay of Endotoxins}

The brine shrimp, Artemia salina, was used as a toxicity biomarker for endotoxins produced by $P$. aeruginosa ATCC9027, according to Barakat and Gohar $^{21}$. Briefly, four different concentrations of endotoxin $(25,50,75$ and $100 \mu \mathrm{g} /$ $\mathrm{ml}$ ) were distributed in glass vials containing $10 \mathrm{ml}$ sterile seawater. Ten live $A$. salina nauplii were equally distributed in each glass vial, incubated at room temperature and the biomarker viable count was monitored under a stereoscopic microscope after $24 \mathrm{hrs}$. Negative control vials contained 10 nauplii in sterile seawater only. The mortality percentage was calculated according to Rajabi et al. 22 :

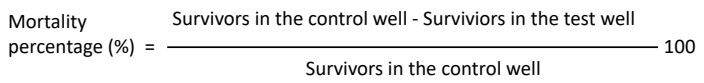

Furthermore, the half-lethal dose $\left(\mathrm{LD}_{50}\right)$ was calculated following Barakat and Beltagy ${ }^{23}$.

\section{Potential Applications of Endotoxin Antiviral activity}

The African green monkey kidney (Vero) cells were used as the host for hepatitis $A$ viral (HAV) infection ${ }^{24}$. Cytotoxicity of endotoxin (1500 $\mu \mathrm{g} / \mathrm{ml}$ ) was measured by MTT method following Bastos et al..$^{25}$ and the protection percentage (\%) for each treated Vero cell was calculated according to the following formula:

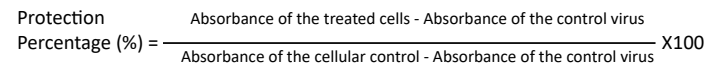

\section{Antitumor activity}

Two tumor cell lines; colon cancer cells (Caco-2) and breast cancer cells (Mcf-7), were kindly provided from the Egyptian Company for Drugs and Veterinary Vaccines, VACSERA CO., Giza, Egypt. Antitumor activity of endotoxin $(1500 \mu \mathrm{g} /$ $\mathrm{ml}$ ) against both tumor cell lines were evaluated using standard methods described by Ibrahim et $a .^{14}$ and the percentage of cell viability was calculated as follows:

Cell viability $(\%)=($ Mean Abs control cells

- Mean Abs treated cells) $\times 100$

Where; Abs is the absorbance at $490 \mathrm{~nm}$

\section{RESULTS AND DISCUSSION}

Endotoxins produced by Gram-negative bacteria were mainly considered as potential components of bacteriological weapons. Recently, this consideration has been slightly changed as some of toxins have useful properties rather than harmful ones ${ }^{26}$. In this context, the current study was conducted in an attempt to produce endotoxins from $P$. aeruginosa ATCC 9027 under optimum conditions with useful potential medical applications.

\section{Screening for endotoxin production}

Screening for endotoxins produced by the selected Gram-negative bacteria showed that $P$. aeruginosa ATCC 9027 recorded the highest concentration of endotoxins $\left(338.59^{\prime} 10^{3}\right.$ IU/ml) (Table 1). Thus, P. aeruginosa ATCC 9027 was selected as the most promising endotoxinproducing strain for further studies. The results (data not shown) showed that the lowest endotoxin concentration exhibiting antibacterial activity, against the test organisms, was $50 \mu \mathrm{g} / \mathrm{l}$, which is considered as the minimum inhibitory 
concentration (MIC) value of the endotoxin produced by $P$. aeruginosa ATCC9027.

Optimization of endotoxin production by $P$. aeruginosa ATCC 9027

The result revealed that the highest endotoxin concentration was detected after $18 \mathrm{hrs}$ of incubation. The endotoxin concentration decreased gradually after $48 \mathrm{hrs}$ of incubation and the endotoxin concentration produced under a shaken incubation condition was always higher than that of a stationary incubation condition.

The results showed that the highest endotoxin concentration, $451.3^{\prime} 10^{3} \mathrm{IU} / \mathrm{ml}$ and $457.3^{\prime} 10^{3} \mathrm{IU} / \mathrm{ml}$ were recorded at both $\mathrm{pH} 7.0$ and $30^{\circ} \mathrm{C}$ incubation temperature, respectively and were selected for next experiments (Fig. 1a, b). Giotis et al. ${ }^{27}$ suggested that low $\mathrm{pH}$ values lead

Table 1. Selected Gram-negative bacteria and their potential as endotoxin producers

\begin{tabular}{|c|c|}
\hline Organism & $\begin{array}{l}\text { Endotoxin conc. } \\
\qquad(\mathrm{IU} / \mathrm{ml})\end{array}$ \\
\hline $\begin{array}{l}\text { Escherichia coli } \\
\text { ATCC } 19404\end{array}$ & $125.86^{\prime} 10^{3}$ \\
\hline $\begin{array}{l}\text { Pseudomonas aeruginosa } \\
\text { ATCC9027 }\end{array}$ & $338.59^{\prime} 10^{3}$ \\
\hline $\begin{array}{l}\text { Aeromonas hydrophila } \\
\text { ATCC } 7966\end{array}$ & $87.71^{\prime} 10^{3}$ \\
\hline $\begin{array}{l}\text { Vibrio damsel } \\
\text { ATCC } 33539\end{array}$ & $37.12^{\prime} 10^{3}$ \\
\hline
\end{tabular}

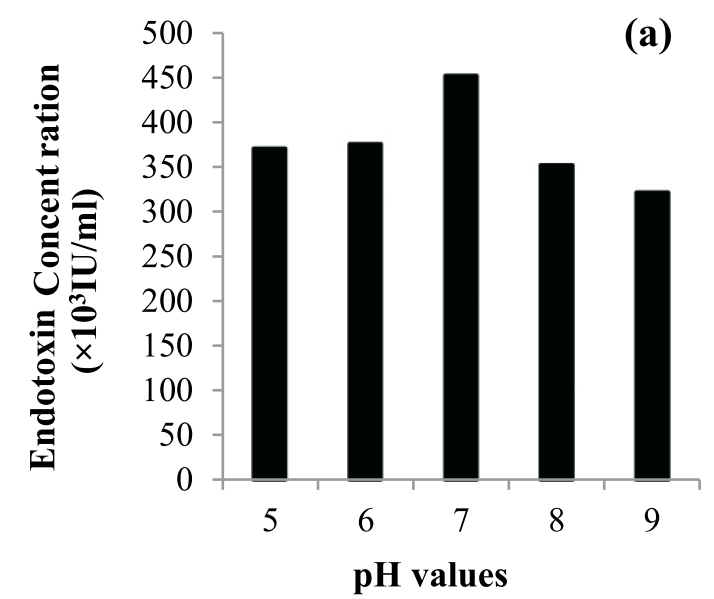

to conformational changes in the branch-chain fatty acids (FAs) of the endotoxin produced by Listeria monocyte that affect its biological activity and membrane fluidity. Kawahara et al. ${ }^{28}$ studied the influence of growth temperature on LPS composition produced by Yersinia pestis. They found that tetra acyl lipid $A$ is most abundant species at $25^{\circ} \mathrm{C}$ with an additional production of penta acyl and hexa acyl species. Further more, (Fig. 2) the maximum concentration of endotoxin produced by $P$. aeruginosa ATCC 9027 was 455.3 $' 10^{3} \mathrm{IU} / \mathrm{ml}$ when incubated at $90 \mathrm{rpm}$ for $18 \mathrm{hrs}$ (Fig. 3). Mahamuni et al. ${ }^{29}$ reported that above the optimum growth temperature, the conformation of the produced endotoxin is highly affected leading to the loss of the attachment of the endotoxin molecule. In addition,

\section{SDS-PAGE analysis}

Bands of endotoxin extracted from $P$. aeruginosa ATCC 9027 were visualized by silver staining of SDS-PAGE, as shown in Fig. 4. LPS was separated into two parts; "lipid A-core" complex (50 kDa) and "O-specific" polysaccharide chain consisting of three bands of 38, 25 and $20 \mathrm{kDa}$. Therefore, the lipid- A core is considered the fastest migrating component and the slower migrating components are $\mathrm{O}$-antigens. Zankharia ${ }^{30}$ analyzed and separated endotoxin extracted from Salmonella enterica serovar typhi by SDS-PAGE followed by silver staining. He showed that LPS molecules had a molecular weight ranging from $10 \mathrm{kDa}$ to $55 \mathrm{kDa}$.

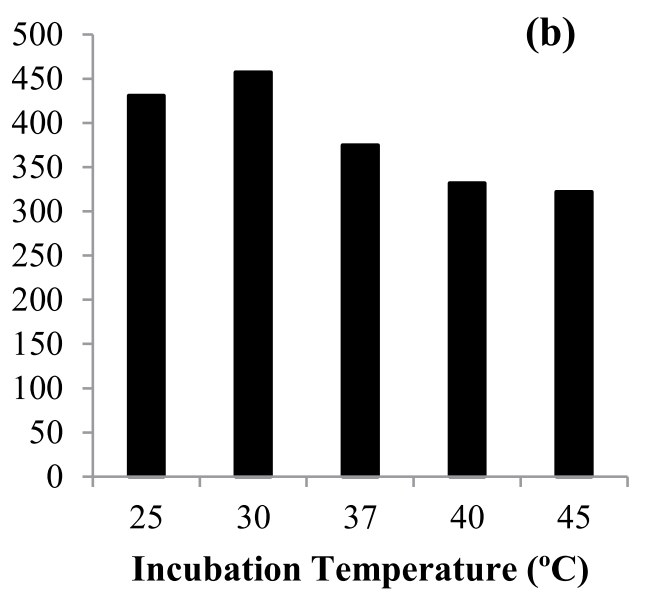

Fig. 1. Effect of different $\mathrm{pH}$ values (a) and incubation temperature (b) on the endotoxin production by $P$. aeruginosa ATCC 9027 


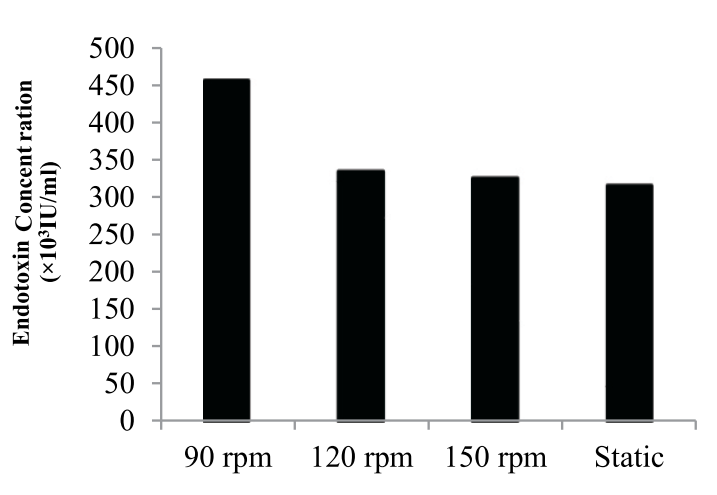

Rate of shaking

Fig. 2. Effect of rate of shaking on the endotoxin production by $P$. aeruginosa ATCC 9027

\section{GC/MS spectroscopy}

The components of endotoxin extracted from $P$. aeruginosa ATCC 9027 were characterized by GC/MS. As shown in Fig. 5, four compounds were detected; $2 \mathrm{H}$ Pyaran, 2,5 diethenyltetrahydro, Tetradecanoic acid, Bis (2 ethylhexyl) phthalate and Dodecanoic acid with a relative retention times of $1.38,19.32,23.18$ and $25.68 \mathrm{~min}$, respectively. The detected compounds are identical with the main components obtained from Serratia rubidaea and reported by Renukadevi et al. ${ }^{31}$. They reported the following components: 3-hydroxytetradecanoic acid (3-OH 14:0), 3- metoxytetradecanoic acid

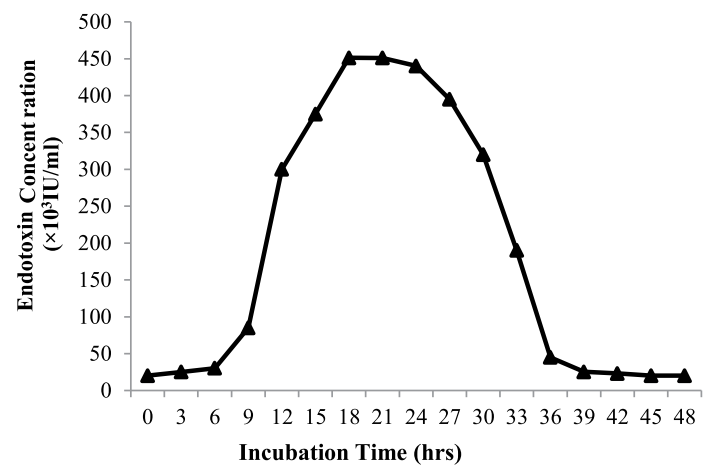

Fig. 3. Time course of the endotoxin production by $P$. aeruginosa ATCC 9027

(3-OMe 14:0) and tetradecenoic acid (14:1). Furthermore, dodecanoic (12:0), tetradecanoic (14:0) and hexadecanoic acid (16:0) were found in significant amounts.

\section{Determination of endotoxin stability}

The extracted endotoxin from $P$. aeruginosa ATCC 9027 showed high thermal stability upon exposure to $120^{\circ} \mathrm{C}$ for $60 \mathrm{~min}$ and the activity decreased (97\%) with the progressive increase in temperature treatment at $200^{\circ} \mathrm{C}$ for $60 \mathrm{~min}$ (Data not shown). This was supported by the findings of Miyamoto et al. ${ }^{19}$, who reported the complete inactivation of endotoxins produced

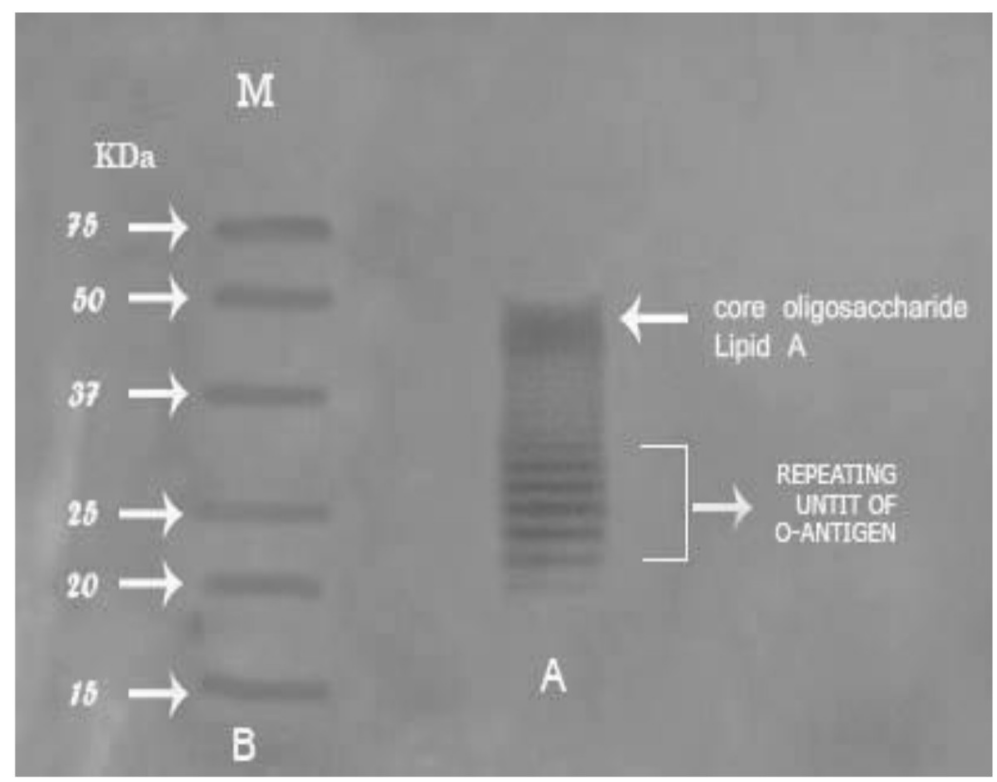

Fig. 4. SDS-PAGE profile of the purified endotoxin from $P$. aeruginosaATCC 9027 Lane A: ladder pattern of purified endotoxin. Lane B: protein marker ranged from $18-75 \mathrm{kDa}$ 
by $E$. coli upon exposure to thermal treatment at $250^{\circ} \mathrm{C}$ for $60 \mathrm{~min}$. In line with this concept, Gorbet and Sefton ${ }^{32}$ reported that endotoxins are highly heat-stable under normal sterilization conditions but the inactivation happened when exposed to $250^{\circ} \mathrm{C}$ for $30 \mathrm{~min}$ or $180 \div \mathrm{C}$ for $3 \mathrm{hrs}$. Thus, soft hydrothermal processing can inactivate endotoxins and this would be useful for the sterilization of medical devices that cannot tolerate the exposer to dry heat at higher temperatures ${ }^{19}$. Gorbet and Sefton $^{32}$ reported that, the endotoxins are highly heat-stable under normal sterilizing conditions but endotoxins can be inactivated upon exposure to $250^{\circ} \mathrm{C}$ for $30 \mathrm{~min}$ or $180^{\circ} \mathrm{C}$ for $3 \mathrm{hrs}$.

Ibrahim et al. ${ }^{15}$ tested four temperature degrees $\left(50,100,150\right.$, and $\left.200^{\circ} \mathrm{C}\right)$ factors on the
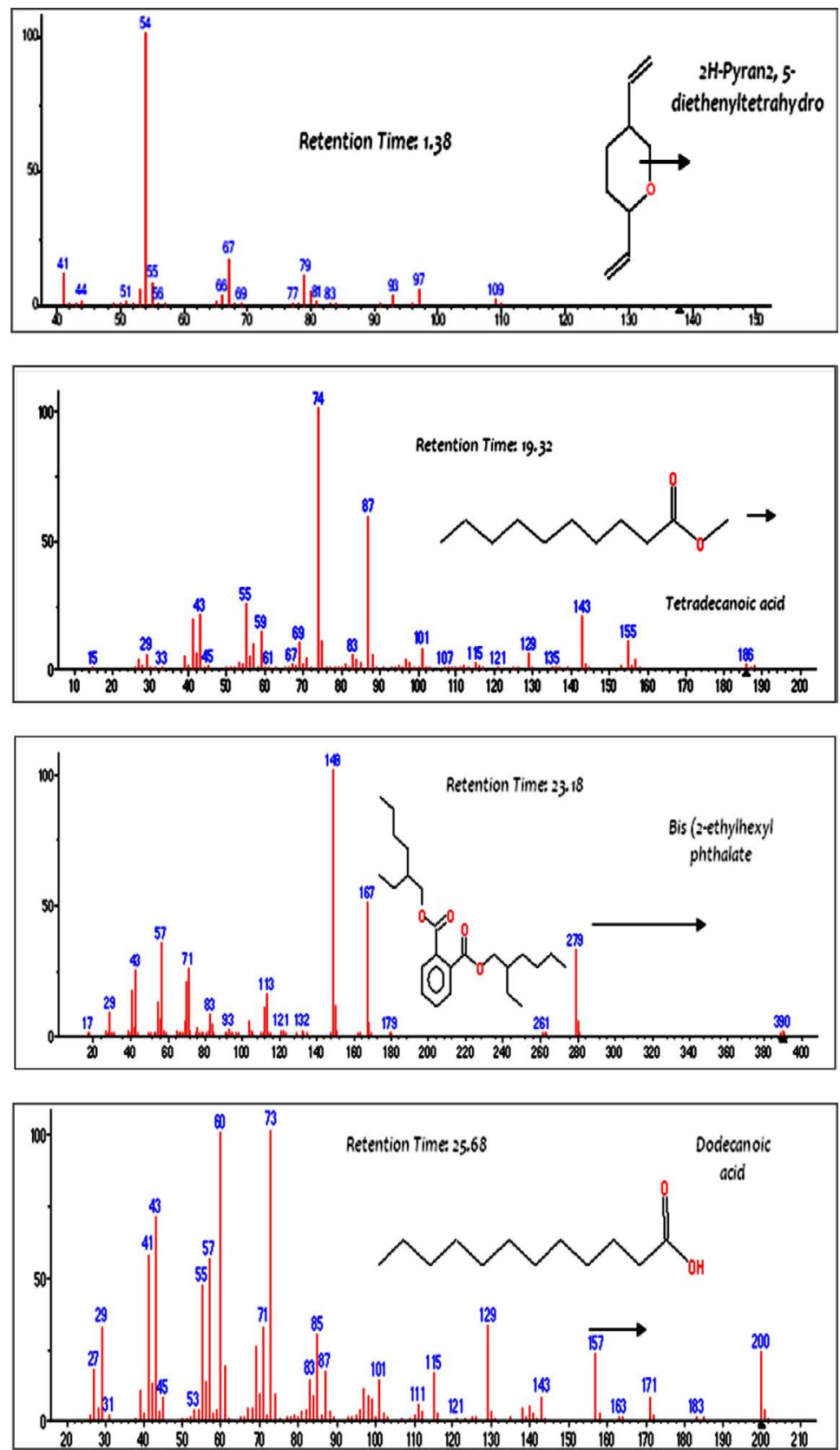

Fig. 5. Mass spectra of major constituents of the endotoxin produced by $P$. aeruginosa ATCC 9027 
stability of endotoxin produced by E. coli AS10. Results revealed that the higher temperature, the lower endotoxin activity and consequently endotoxin concentration decreased upon the increase of temperature. The endotoxin lost about $88.6 \%$ and $94 \%$ of its activity/concentration at 150 and $200^{\circ} \mathrm{C}$, respectively. Miyamoto et al. ${ }^{19}$ studied the mechanism of the hydrothermal treatment effect on the endotoxin stability. They suggested that inactivation occurs via hydrolysis of the ketosidic linkage between 2-keto-3-deoxyoctonic acid of the core oligosaccharide and lipid A, or glycosidic phosphate or fatty acids within lipid $A$. Schromm et al..$^{33}$ explained that the hydrothermal treatment effects the distribution of negative charges within the hydrophilic part of lipid A, which strongly influences it's the overall molecular conformation.

Chemical treatment of endotoxin extracted from $P$. aeruginosa ATCC 9027, either by $1 \mathrm{~N} \mathrm{NaOH}, \mathrm{HCl}$ or ethyl alcohol ( $70 \%$ and $100 \%$ ), resulted in detectable lowering in its activity (44.7\%, 68.5\%, $64.7 \%$ and $88.5 \%$, respectively) after 60 min of treatment as reported by Magalh Tes et al. ${ }^{34}$. Ibrahim et al..$^{15}$ examined four $\mathrm{NaOH}$ concentrations $(0.1,0.2,0.5$, and $1.0 \mathrm{~N})$ influencing the stability of endotoxin produced by $E$. coli AS10. They concluded that endotoxin activity and concentration decreased upon the increase of

$\mathrm{NaOH}$ normality and endotoxin lost about $69 \%$ and $81 \%$ of its activity/concentration at $0.5 \mathrm{~N}$ and $1 \mathrm{~N}$, respectively. Further more, they emphasized that alkaline and acidic treatment changes irreversibly the endotoxin conformation which causes the loss of its activity and resulted in toxicity reduction and the deacylated LPS with the elimination of ester-linked fatty acids and changes occurred in the carbohydrate moiety of the lipid A component.

\section{Endotoxin bio-toxicity and applications}

For toxicity test toward $A$. salina, different concentrations of endotoxin from 25 to $100 \mu \mathrm{g} / \mathrm{ml}$ were used and the mortality percentage of nauplii was estimated after $24 \mathrm{hrs}$. The results, presented in Table 2, indicated that the endotoxin produced by $P$. aeruginosa ATCC 9027 had a moderate toxicity level with $\mathrm{LD}_{50}$ value of $102.99 \mu \mathrm{g} / \mathrm{ml}$.

Table 2. Bio-toxicity of different endotoxin concentrations produced by $P$. aeruginosa ATCC 9027

\begin{tabular}{lcccc}
\hline $\begin{array}{l}\text { Conc. } \\
(\mu \mathrm{g} / \mathrm{ml})\end{array}$ & $\begin{array}{c}\text { Log } \\
\text { Conc. }\end{array}$ & $\begin{array}{c}\text { Mortality } \\
(\%)\end{array}$ & $\begin{array}{c}\text { Log } \\
\mathrm{LD}_{50}\end{array}$ & $\begin{array}{c}\mathrm{LD}_{50} \\
(\mu \mathrm{g} / \mathrm{ml})\end{array}$ \\
\hline 25 & 1.40 & 10 & 2.01 & 102.99 \\
50 & 1.70 & 30 & & \\
75 & 1.88 & 40 & & \\
100 & 2.00 & 50 & & \\
\hline
\end{tabular}
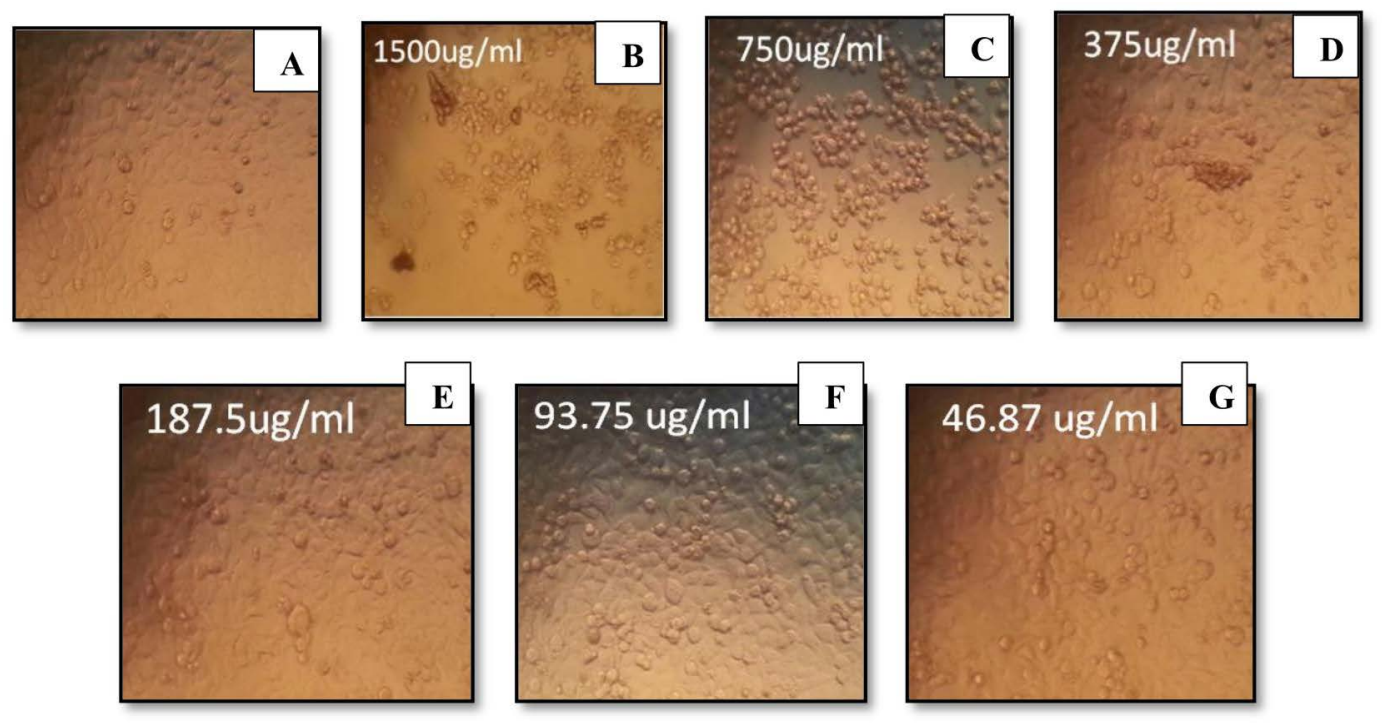

Fig. 6. Effect of different endotoxin concentrations on cell viability of Caco-2

(A) Control (untreated) Caco-2 cells. (B-G) Caco-2-treated cells with endotoxins 
Antibacterial activity of the endotoxin produced from $P$. aeruginosa ATCC 9027 was determined. The results revealed its antibacterial potential against Gram-negative bacterial pathogens as Salmonella typhimurium ATCC 14028, Escherichia coli ATCC 19404, and Klebsiella granulomatis ATCC 43816 and against Grampositive bacterial pathogens as Bacillus cereus ATCC 33018. Ibrahim et al. ${ }^{15}$ evaluated the endotoxin produced by $E$. coli AS10 that showed potent antibacterial activity against $S$. aureus ATCC6538, B. cereus ATCC 33018 and K. pneumonia ATCC 43816. They highlighted the contribution of the antibacterial activity of endotoxin in driving the innate immune response, which is considered the first line of defense against pathogens through the core part in endotoxin signaling pathway produced LPS-binding protein (LBP).

A low antioxidant activity of the endotoxin from $P$. aeruginosa ATCC 9027 with $\mathrm{LC}_{50}$ value of $688 \mu \mathrm{g} / \mathrm{ml}$. The endotoxin produced by Ibrahim et al. ${ }^{15}$ from marine $E$. coli AS10 showed a considerable antioxidant activity under the experimental conditions with $\mathrm{LC}_{50}$ of $14.2 \mu \mathrm{g} /$ $\mathrm{ml}$. Further more, the endotoxin $(1500 \mu \mathrm{g} / \mathrm{ml})$ exhibited relatively weak antiviral activity (5.2\%) against Vero cells infected with HAV. Campbell and White ${ }^{35}$ reported that bacterial endotoxin was unable to protect effectively the mice infected with lethal doses of Mengo virus that is related to the level of circulating interferon produced. However, El Tayeb and Hanson ${ }^{36}$ reported that the titer of Newcastle disease virus (NDV) in infected chickens significantly $(P<0.05)$ decreased when inoculated with $E$. coli endotoxin before 3 days of exposure to NDV.

Furthermore, the cytotoxicity of endotoxin produced by $P$. aeruginosa ATCC 9027 was analyzed for its antitumor activity. $P$. aeruginosa endotoxin showed sharp decrease in the percentage of cell viability, $87 \%$ and $92 \%$, of both Caco-2 and Mcf-7 cell lines, respectively (Figs. 6, 7). Similarly, Sourek and Oravec ${ }^{37}$ found that endotoxins of Shigella dysenteriae exhibited 76-92\% tumoricidal effect against N'meth-Kellner mouse lymphoma cells in an in vitro assay. Nerkar and Bandekar ${ }^{38}$ showed that endotoxin of Salmonella typhimurium, irradiated with gamma radiation, exhibited antitumor activity against S180 cells in Swiss mice and gave 90\% survival of the infected mice. Bandekar and Nerkar ${ }^{39}$ reported the antitumor activity of lipopoly-saccharide and radio-detoxified lipopoly-saccharide of Vibrio parahaemolyticus
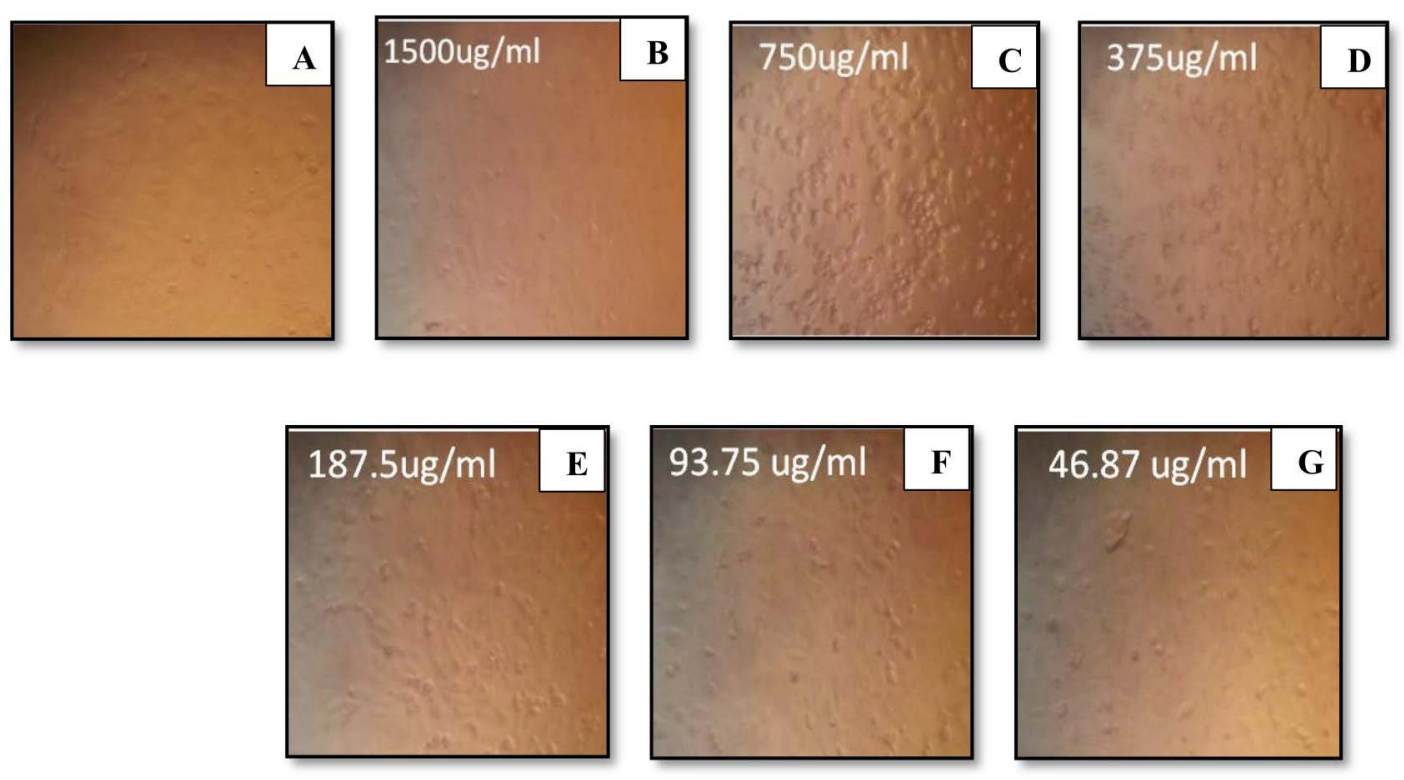

Fig. 7. Effect of different endotoxin concentrations on cell viability of Mcf-7 (A) Control (untreated) Mcf-7 cells. (B-G) Mcf-7-treated cells with endotoxins 
In conclusion, the present study showed the successful endotoxin production by $P$. aeruginosa ATCC 9027 and its use as an unconventional new anticancer therapeutic agent. This requires more clinical evaluation using animal model experiments to assess its pharmacological kinetics and usefulness for both colon and breast cancer treatment.

\section{ACKNOWLEDGEMENT}

The authors are sincerely grateful to members in Delta-pharm Company, Al Obour, Egypt, for their valuable assistance in endotoxin analysis experiments.

\section{CONFLICTS OF INTEREST}

The author declares that there are no conflict of interest.

\section{REFERENCES}

1. Al ShiekhEid M., Alharbi S.Bacterial Endotoxin Released by Different Types of Mouthwash. World Appl. Sci J., 2012; 20:305-309.

2. Fung F., Su M., Feng H-T., Li S. Extraction, separation and characterization of endotoxins in water samples using solid phase extraction and capillary electrophoresislaser induced fluore-scence. Sci Rep., 2017; 7: 10774.

3. Rezania S., Amirmozaffari N., Tabarraei B., JeddiTehrani M., Zarei O., Alizadeh R., Masjedian F., Zarnani A. Extraction, Purification and Characterization of Lipopolysaccharide from Escherichia coli and Salmonella typhi. Avicenna J. MedBiotechnol, 2011; 3: 1-9.

4. Tirsoaga A., Novikov A., Adib-Conquy M., Werts C., Fitting C., Cavaillon J-M., Caroff M. Simple Method for Repurification of Endotoxins for Biological Use. Appl. Environ. Microbiol., 2007; 73: 1803-1808.

5. Culbertson R., Osburn B. The biological effects of bacterial endotoxin: A short review. Vet. Res. Commun., 1980; 4: 3-14.

6. Dungan R., Leytem A. The effect of extraction, storage, and analysis techniques on the measurement of airborne endotoxin from a large dairy. Aerobiologia, 2009; 25: 265-273.

7. Kirikae T., Kirikae F., Saito S., Tominaga K., Tamura H., Uemura Y., Yokochi T., Nakano M. Biological Characterization of Endotoxins Released from Antibiotic-Treated Pseudomonas aeruginosaand Escherichia coli. Antimicrob. Agents Chemother., 1998; 42: 1015-1021.

8. Galanos C., Freudenberg M. Bacterial endotoxins: biological properties and mechanisms of action. Mediators. Inflamm., 1993; 2: S11-S16.

9. Hirakata Y., Kirikae T., Kirikae F., Yamaguchi T., Izumikawa K., Takemura H., Maesaki S., Tomono K., Yamada Y., Kamihira S., Nakano M., Kitamuraz S., Kohno S. Effect of Pseudomonas aerugino-saexotoxin
A on endotoxin-induced tumor necrosis factor production in murine lung. J. Med. Microbiol., 1999; 48: 471-477.

10. Najafzadeh F., Shapouri R., Rahnema M., Azar S., Kianmehr A. Pseudomonas aeruginosa PAO-1 Lipopolysaccharide-Diphtheria toxoid conjugate vaccine: preparation, characterization and immunogenicity. Jundishapur J. Microbiol., 2015; 8: e17712.

11. Pier G. Pseudomonas aeruginosalipopoly-saccharide: a major virulence factor, initiator of inflammation and target for effective immunity. Int. J. Med.Microbiol., 2007; 297: 277-295.

12. Karpioski T., Szkaradkiewicz A. Anticancer peptides from bacteria. Bangladesh J. Pharmacol., 2013; 8: 343-348.

13. Tanamoto K-I., Abe C., Homma J., Kojima Y. Regions of the lipopolysaccharide of Pseudomonas aeruginosaessential for antitumor and interferoninducing activities. Eur. J. Biochem., 1979; 97: 623-629.

14. lihara H, Niwa T, Shah M, Nhung P, Song S, Hayashi M, Ohkusa K, ItohY, Makino S, Ezaki T. Rapid multiplex immunofluorescent assay to detect antibodies againstBurkholderiapseudomallei and taxonomically closely related non-fermenters. Jpn. J. Infect. Dis., 2007; 60: 230-234.

15. Ibrahim H., El-Naggar H., El-Damhougy K., Bashar M., AbouSenna F. Callyspongiacrassa and C. siphonella (Porifera, Callyspongiidae) as a potential source for medical bioactive substances, Aqaba Gulf, Red Sea, Egypt. J. Basic Appl. Zool., 2017; 78: 7.

16. Jayammal D., Sivakumar T. Antibacterial activity of protein extract of marine Pseudomonas aeruginosa against bacterial pathogens. Int. J. Curr. Microbiol. Appl. Sci., 2013; 2: 207-216.

17. Doruk T, GarganErsoy Z, "ncel M, Gedak S. High levels of polyphosphate kinase affects not only endotoxin production but also acid tolerance of Bacillus thuringiensis. Turkish J. Biol., 2016; 40: 1168-1177.

18. Binding N, Jaschinski S, Werlich S, Bletz S, Witting $U$. Quantification Of bacterial lipopoly-saccharides (endotoxin) by GC-MS determination of 3-hydroxy fatty acids. J. Environ. Monit., 2004; 6: 65-70.

19. Miyamoto T, Okano S, KasaiN. Inactivation of Escherichia coli endotoxin by soft hydrothermal processing. Appl Environ. Microbiol., 2009; 75 : 5058-5063.

20. Govers C, Tomassen M, Rieder A, Balance S, Knutsen $S$, Mes J. Lipopolysaccharide quantification and alkalibased inactivation in polysaccharide preparations to enable in vitro immune modulatory studies. Bioact. Carbohydr. Dietary Fibre, 2016; 8: 15-25.

21. Barakat K., Gohar Y. Antimicrobial agents produced by marine Aspergillusterreus var. africanus against some virulent fish pathogens. Indian J. Microbiol., 2012; 52 : 366-372.

22. Rajabi S, Ramazani A, Hamidi M, Naji T. Artemiasalina as a model organism in toxicity assessment of nanoparticles. DARU J. Pharm.Sci., 2015; 23: 20.

23. BarakatK, Beltagy E. Bioactive phthalate from marine Streptomyces ruber EKH2 against virulent fish pathogens. Egyptian J. Aquatic Res.,2015; 41: 49-56. 
24. Ashida M., Hara H., Kojima H., Kamimura T., Ichida F., Hamada C. Propagation of Hepatitis A Virus in Hybrid Cell Lines Derived from Marmoset Liver and Vero Cells. J. Gen. Virol., 1989; 711: 2487-2494.

25. Bastos J., Kohn L., Fantinatti-Garboggini F., Padilla M., Flores E., da Silva B., de Menezes C., Arns C. Antiviral Activity of Bacillus sp. Isolated from the Marine Sponge Petromicacitrina against Bovine Viral Diarrhea Virus, a Surrogate Model of the Hepatitis C Virus. Viruses, 2013; 5: 1219-1230.

26. Ibrahim H., Roushdy M., Sofy A., Shimy A., El-Dougdoug K. Endotoxin production by marine $E$. coli AS10 and its antimicrobial activity. J. Microbiol. Res., 2017;7: 68-78.

27. Giotis E., McDowell D., Blair I., Wilkinson B. Role of branched-chain fatty acids in $\mathrm{pH}$ stress tolerance in Listeria monocyte genes. Appl. Environ. Microbiol., 2007; 73: 997-1001.

28. Kawahara K., Tsukano H., Watanabe H., Buko Lindner B., Matsuura M. Modification of the structure and activity of lipid A in Yersinia pestislipopolysaccharide by growth temperature. Infect. Immun., 2002; 70: 4092-4098.

29. Mahamuni P, Patil R, Ghosh S.Proteolytic and lipolytic properties of endotoxins (enterotoxins) produced by Salmonella typhiNCIM 5255, Salmonella typhimurium NCIM 2501 and Shigella-flexneri NCIM 5265. Inter. Food Res. J., 2017; 24: 2685-2688.

30. Zankharia U. Extraction, characterizationand determination of immmunoreactivityof lipopolysaccharide ofSalmonellatyphi. J. Sci.Technol., 2015; 4: 224-229.

31. Renukadevi K., Angayarkanni J., Karunakaran G.
Extraction and characterization of lipopoly-saccharide from Serratiarubidaea and its cytotoxicity on lung cancer cell line $\mathrm{NCl} \mathrm{H69.} \mathrm{ActaTechnicaCorviniensis} \mathrm{-}$ Bulletin of Engineering, 2012; 2: 97-101.

32. Gorbet M., Sefton M. Endotoxin: The Uninvited Guest. Biomaterials, 2006; 26: 6811-6817.

33. Schromm A, Brandenburg K, Loppnow $H$, Zinhringer $U$, Rietschel E, Carroll S, Koch M, Kusumoto S, Seydel $U$. Thecharge of endotoxin molecules influences their conformation andinterleukin- 6 inducing capacity. J. Immunol.,1998; 161: 5464-5471.

34. Magalhtes P., Lopes A., Mazzola P., Rangel-Yagui C., Penna T., Jr A. Methods of Endotoxin Removal from Biological Preparations: a Review. J. Pharm. Pharm. Sci.,2007; 10: 388-404.

35. Campbell J., White S. A comparison of the prophylactic and therapeutic effects of poly I:C and endotoxin in mice infected with Mengo virus. Canadian J. Microbiol.,1976; 22: 1595-1602.

36. El Tayeb A., Hanson R. The interaction between Newcastle disease virus and Escherichia coli endotoxin in chickens.Avian Diseases,2001; 45: 313-20.

37. Sourek J., Oravec C. Antitumor activity of bacterial endotoxins and their subunits in in vitro test. Eur. J.Public Health, 1994; 2: 62-65.

38. Nerkar D, Bandekar J. Stimulation of macrophages and antitumor activity of radiodetoxified endotoxin. Microbiol. Immunol., 1986; 30: 893-901.

39. Bandekar J., Nerkar D. Antitumor activity of lipopolysaccharide and radio-detoxified lipopolysaccharide of Vibrio parahaemolyticus. Microbiol. Immunol, 1987; 31: 675-681. 